\title{
Karkas, Lemak Abdominal dan Status Kesehatan Ayam Ras Pedaging yang Diberi Seduhan Kelopak Bunga Rosela (Hibiscus sabdariffa Linn)
}

\section{(Carcass, Abdominal Fat and Health Status of Broiler by Adding Extract of Roselle Flower (Hibiscus sabdariffa Linn))}

\author{
Sadarman $^{1}$, Saleh $E^{1}$, Johan $A^{2}$ \\ ${ }^{1}$ Program Studi Peternakan, Fakultas Pertanian dan Peternakan \\ ${ }^{2}$ Alumni Program Studi Peternakan, Fakultas Pertanian dan Peternakan \\ Universitas Islam Negeri Sultan Syarif Kasim Riau, Jl. Subrantas Km. 15, Pekanbaru 28293 \\ sadarman@uin-suska.ac.id
}

\begin{abstract}
Roselle is an herbal that is rich in vitamin C. This vitamin serves as an antioxidant, can reduce stress when replace cages, stress due to changes in extreme weather and quicken recovery of broiler health. This study aims to determine the optimum concentration of use infusion Roselle petals. The research design used was Completely Randomized Design with 4 treatment levels awarding steeping flower petals Roselle, i.e. $0.0 ; 1.3 ; 2.6$ and $3.9 \mathrm{~g} / \mathrm{l}$ drinking water. The treatment was repeated four times. Observations were conducted on day $35^{\text {th }}$. The parameters observed were the final weight, weight and percentage of carcass, weight and abdominal fat percentage as well as health status of broiler. The results of this study showed that giving Roselle petals on a steeping broiler has not yet provided any significantly influence $(\mathrm{P}>0.05)$ towards the final weight, weight and percentage of carcass, weight and abdominal fat percentage and antibody titrate.
\end{abstract}

Key Words: Carcass, Abdominal Fat, Antibody Titrate, Broiler, Roselle Flowers

\begin{abstract}
ABSTRAK
Rosela merupakan tanaman herbal yang kaya dengan vitamin C. Vitamin ini berfungsi sebagai antioksidan, dapat mengurangi stres pada saat pindah kandang, stres akibat perubahan cuaca ekstrim dan mempercepat pemulihan kesehatan ayam ras pedaging. Penelitian ini bertujuan untuk mengetahui konsentrasi optimal penggunaan seduhan kelopak bunga rosela. Rancangan penelitian yang digunakan adalah rancangan acak lengkap (RAL) dengan 4 perlakuan level pemberian seduhan kelopak bunga rosela, yakni 0,0; 1,3; 2,6 dan 3,9 g/l air minum. Perlakuan tersebut diulang sebanyak 4 kali. Pengamatan dilakukan pada hari ke-35. Parameter yang diamati adalah bobot badan akhir, berat dan persentase karkas, berat dan persentase lemak abdominal, serta status kesehatan ayam ras pedaging. Hasil penelitian ini menunjukkan bahwa pemberian seduhan kelopak bunga rosela pada ayam ras pedaging belum memberikan pengaruh yang nyata $(\mathrm{P}>0,05)$ terhadap berat badan akhir, berat dan persentase karkas, berat, persentase lemak abdominal dan titer antibodi.
\end{abstract}

Kata Kunci: Karkas, Lemak Abdominal, Titer Antibodi, Ayam Ras Pedaging, Kelopak Bunga Rosela

\section{PENDAHULUAN}

Peningkatan produksi karkas ayam ras pedaging dapat dilakukan dengan beragam cara, salah satunya adalah dengan penggunaan tanaman herbal. Tanaman herbal dapat digunakan untuk ayam ras pedaging sebagai alternatif menggantikan produk sintetis, seperti antibiotika yang dapat mengakibatkan resistensi pada konsumen. Saat ini, tanaman herbal banyak digunakan peternak karena dipercaya dapat mencegah dan mengobati berbagai macam penyakit. 
Kebanyakan tanaman obat yang telah dikaji membuktikan adanya kerja imunostimulator. Pemakaian tanaman obat sebagai imunostimulator bertujuan untuk menekan atau mengurangi infeksi virus dan bakteri intraseluler, untuk mengatasi imunodefisiensi atau sebagai perangsang pertumbuhan sel-sel pertahanan tubuh dalam sistem imunitas (Block \& Mead 2003). Salah satu tanaman obat yang zat aktifnya dapat dimanfaatkan oleh ternak adalah kelopak bunga rosela (Hibiscus sabdariffa Linn).

Bunga rosela merupakan anggota famili Malvaceae. Kelopak bunga rosela banyak dimanfaatkan sebagai bahan makanan dan minuman. Rosela mengandung protein, vitamin terutama vitamin $\mathrm{C}$, mineral, dan komponen bioaktif seperti asam organik, phytosterol, polyphenol, antosianin dan flavonoid. Antosianin, flavonoid dan vitamin $\mathrm{C}$ berfungsi sebagai antioksidan. Fungsi vitamin $\mathrm{C}$ lainnya adalah untuk mengurangi stres pada saat ayam pindah kandang, akibat perubahan cuaca ekstrim, dan mempercepat pemulihan kesehatan pasca-sakit (Ensminger 1992; Tabbu 2000).

Pemberian seduhan kelopak bunga rosela dalam air minum ayam ras pedaging belum dilaporkan, padahal dilihat dari kandungan nutrisinya seperti pada Tabel 1, bunga rosela dapat dimanfaatkan untuk memperbaiki performans ayam ras pedaging.

Tabel 1. Komposisi nutrisi kelopak bunga rosela per $100 \mathrm{~g}$ bahan

\begin{tabular}{lc}
\hline \hline Komposisi nutrisi & Jumlah \\
\hline Kalori (kal) & 44,00 \\
Air $(\mathrm{g})$ & 86,20 \\
Protein $(\mathrm{g})$ & 1,60 \\
Lemak $(\mathrm{g})$ & 0,10 \\
Karbohidrat $(\mathrm{g})$ & 11,10 \\
Serat $(\mathrm{g})$ & 2,50 \\
Vitamin C (mg) & $68,00^{*}$ \\
\hline
\end{tabular}

Sumber: Maryani \& Kristina (2008); *Mardiah et al. (2009)

Berdasarkan informasi tersebut maka telah dilakukan kajian tentang pemberian seduhan kelopak bunga rosela untuk meningkatkan berat badan akhir, berat dan persentase karkas, berat dan persentase lemak abdominal serta status kesehatan ayam ras pedaging.

Penelitian ini bertujuan untuk mengetahui konsentrasi optimal penggunaan seduhan kelopak Bunga Rosela terhadap berat badan akhir, berat dan persentase karkas, berat dan persentase lemak abdominal serta status kesehatan ayam ras pedaging.

\section{MATERI DAN METODE}

\section{Jenis ayam}

Dalam penelitian ini digunakan anak ayam ras pedaging umur 7 hari strain $C o b b 500$ tanpa pembeda jenis kelamin (unsexing) sebanyak 60 ekor.

\section{Ransum yang digunakan}

Ransum yang digunakan adalah ransum komersial, yakni Vivo 311 untuk periode starter dan Vivo 511 untuk periode finisher. 


\section{Kelopak bunga rosela}

Kelopak bunga rosela yang digunakan adalah kelopak bunga dalam bentuk kering yang dibeli dari kios rempah-rempah di pasar tradisional Kota Pekanbaru. Prosedur pembuatan seduhan kelopak bunga rosela mengacu pada Yulrahmen (2008), selanjutnya dapat dilihat pada Gambar 1.

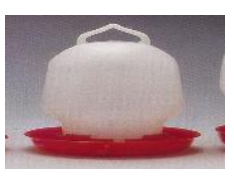

T1: 0 g rosela

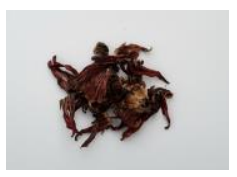

$\mathrm{T} 2: 1,3 \mathrm{~g}$ rosela

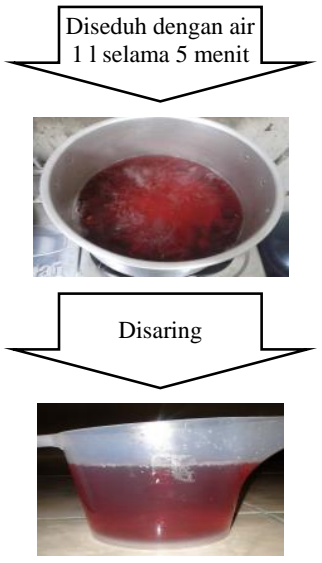

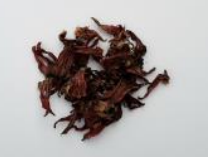

T3: $2,6 \mathrm{~g}$ rosela
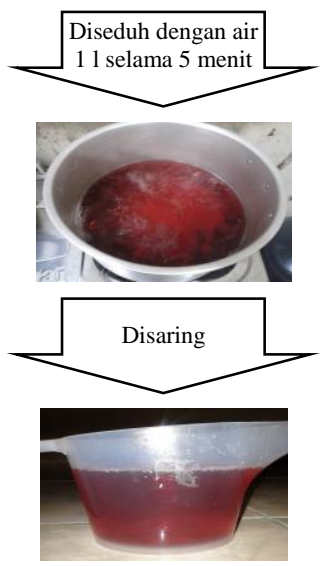

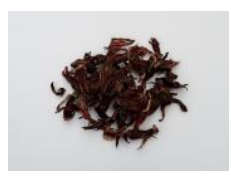

$\mathrm{T} 4: 3,9 \mathrm{~g}$ rosela
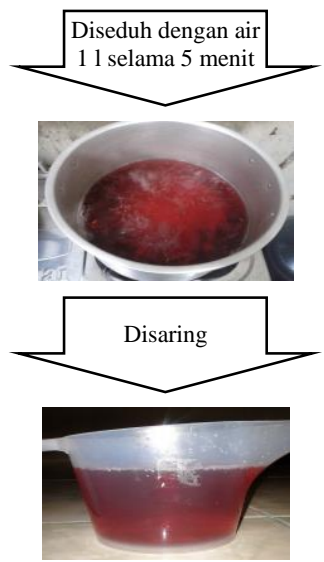

Gambar 1. Pembuatan seduhan kelopak bunga rosela

\section{Perlakuan Seduhan}

Penelitian ini merupakan penelitian eksperimental dengan menggunakan Rancangan Acak Lengkap (RAL), 4 perlakuan dan 4 ulangan. Ayam ras pedaging diberi ransum komersial dan seduhan kelopak bunga rosela dalam bentuk kering. Adapun dosis perlakuan yaitu: (1) T1: Ransum komplit dan air ledeng (kontrol); (2) T2: T1 + air seduhan kelopak bunga rosela 1,3 g/l air minum; (3) T3: T1 + air seduhan kelopak bunga rosela 2,6 g/l air minum; dan (4) T4: T1 + air seduhan kelopak bunga rosela 3,9 g/l air minum.

\section{Vaksin ND}

Vaksin ND pertama dilakukan pada hari keempat dengan aplikasi melalui tetes mata. Vaksinasi kedua diberikan pada hari ke-21 dengan aplikasi melalui injeksi intramuskuler.

\section{Pemotongan ayam ras pedaging}

Pemotongan ayam ras pedaging dilakukan setelah pemeliharan selama 35 hari. Ayam ras pedaging diambil secara acak pada 16 kandang masing-masing 1 ekor untuk dipotong. Penyembelihan ayam ras pedaging mengacu pada Parry (1989) dan Soeparno (1992).

\section{Peubah penelitian}

Peubah yang diamati dalam penelitian ini adalah berat badan akhir, berat karkas, persentase karkas, berat lemak abdominal, persentase lemak abdominal dan titer antibodi ayam ras pedaging. 


\section{Analisis data}

Data penelitian yang didapat ditabulasi dan diolah secara statistik dengan menggunakan analisis sidik ragam menurut Rancangan Acak Lengkap (RAL) (Steel dan Torrie 1993).

\section{HASIL DAN PEMBAHASAN}

\section{Berat badan ayam ras pedaging}

Data berat badan akhir ayam ras pedaging yang diberi seduhan kelopak bunga rosela (Hibiscus sabdariffa Linn) dapat dilihat pada Tabel 2.

Tabel 2. Berat badan akhir ayam ras pedaging yang diberi seduhan kelopak bunga rosela

\begin{tabular}{lc}
\hline \hline Air seduhan kelopak bunga rosela $(\mathrm{g} / \mathrm{l})$ & Berat badan akhir $(\mathrm{g} / \mathrm{ekor})$ \\
\hline T1: 0,00 & $2.208,50 \pm 178,91$ \\
T2: 1,30 & $2.320,12 \pm 304,68$ \\
T3: 2,60 & $2.247,03 \pm 150,03$ \\
T4: 3,90 & $2.098,50 \pm 220,90$ \\
\hline
\end{tabular}

Tabel 2 memperlihatkan bahwa berdasarkan hasil analisis sidik ragam pemberian seduhan kelopak bunga rosela berbeda tidak nyata $(\mathrm{P}>0,05)$ terhadap berat badan akhir ayam ras pedaging yang digunakan dalam penelitian ini.

\section{Berat dan persentase karkas}

Pengaruh seduhan kelopak bunga rosela terhadap berat dan persentase karkas masingmasing perlakuan disajikan dalam Tabel 3 .

Tabel 3. Berat dan persentase karkas ayam ras pedaging yang diberi seduhan kelopak bunga rosela

\begin{tabular}{lcc}
\hline \hline Air seduhan kelopak bunga rosela $(\mathrm{g} / \mathrm{l})$ & Berat karkas $(\mathrm{g} / \mathrm{ekor})$ & Persentase karkas $(\%)$ \\
\hline T1: 0,00 & $1.657,01 \pm 106,72$ & $75,13 \pm 2,23$ \\
T2: 1,30 & $1.772,31 \pm 402,37$ & $75,94 \pm 10,68$ \\
T3: 2,60 & $1.613,53 \pm 112,50$ & $71,80 \pm 0,57$ \\
T4: 3,90 & $1.571,51 \pm 181,09$ & $74,85 \pm 1,55$ \\
\hline
\end{tabular}

Hasil analisis sidik ragam, seluruh perlakuan menunjukkan berbeda tidak nyata $(\mathrm{P}>0,05)$ terhadap capaian berat karkas (Tabel 3). Hal ini diduga ada hubungan antara palatabilitas atau kesukaan ayam yang menurun pada air minum yang diberikan, sehingga ayam lebih sedikit minum, dengan demikian jumlah zat aktif yang dikandung kelopak bunga rosela itu sendiri berkurang. Dampaknya, peran aktif zatnya pun tidak maksimal.

Di sisi lain, peningkatan atau penurunan berat karkas ada hubungannya dengan peningkatan atau penurunan berat badan. Hal ini sesuai dengan pendapat Soeparno (1994), produksi karkas pada umumnya berhubungan dengan berat badan. Hal lainnya dikemukakan Siregar et al. (1980), berat karkas dapat dipengaruhi oleh strain, jenis kelamin, umur, berat badan dan makanan. Namun, faktor genetik dan lingkungan juga berperan aktif dalam memengaruhi capaian berat karkas (Warwick et al., 1995). 
Dari analisis sidik ragam, pemberian seduhan kelopak bunga rosela 1,3 sampai dengan $3,9 \mathrm{~g} / \mathrm{l}$ air minum masih manghasilkan perbedaan tidak nyata $(\mathrm{P}>0,05)$ terhadap persentase karkas. Siregar et al. (1980) menyatakan bahwa persentase karkas normal untuk ayam ras pedaging berkisar 60-75\% dari berat badan. Hal yang sama dikemukakan North (1984), persentase karkas ayam ras pedaging yang dipelihara sampai umur 35 hari sekitar $65-75 \%$ dari bobot badan.

Hasil penelitian ini secara keseluruhan masih berada dalam batasan persentase karkas normal, yakni 71,80-75,94\%. Menurut Rinaldi (2004), capaian persentase karkas yang optimal tidak saja dipengaruhi oleh manajemen pemeliharaan secara keseluruhan, bobot karkas yang berbanding lurus dengan persentase karkas juga dapat memengaruhi capaian persentase karkas.

\section{Berat dan persentase lemak abdominal}

Berat dan persentase lemak abdominal ayam ras pedaging yang diberi seduhan kelopak bunga rosela dapat dilihat pada Tabel 4 . Tabel 4 menunjukkan bahwa pemberian seduhan kelopak bunga rosela tidak nyata berpengaruh $(\mathrm{P}>0,05)$ pada berat dan persentase lemak abdominal yang dipelihara sampai dengan umur 35 hari. Tidak adanya pengaruh pemberian kelopak bunga rosela ini terhadap peningkatan berat lemak abdominal ini diduga karena kandungan vitamin $\mathrm{C}$ dalam seduhan kelopak bunga rosela belum mampu memperbaiki sistem metabolisme tubuh.

Tabel 4. Berat dan persentase lemak abdominal ayam ras pedaging yang diberi seduhan kelopak bunga rosela

\begin{tabular}{lcc}
\hline \hline Air seduhan kelopak bunga rosela $(\mathrm{g} / \mathrm{l})$ & $\begin{array}{c}\text { Berat lemak abdominal } \\
\text { (g/ekor) }\end{array}$ & $\begin{array}{c}\text { Persentase lemak } \\
\text { abdominal }(\%)\end{array}$ \\
\hline T1: 0,00 & $60,83 \pm 9,78$ & $2,76 \pm 0,45$ \\
T2: 1,30 & $62,29 \pm 12,75$ & $2,69 \pm 0,47$ \\
T3: 2,60 & $68,38 \pm 5,37$ & $3,06 \pm 0,39$ \\
T4: 3,90 & $60,61 \pm 11,60$ & $2,90 \pm 0,62$ \\
\hline
\end{tabular}

Menurut Soeparno (1994), lemak abdominal adalah indikasi ketidakefisienan ternak dalam memanfaatkan ransum. Ditambahkannya bahwa lemak abdominal juga merupakan sumber terbesar dari susut masak bila dibuang saat pemasakan. Sementara Wahju (2004) menyatakan bahwa lemak abdominal diperlukan jika digunakan sebagai cadangan energi pada saat suplai makanan berkurang.

Pemberian seduhan kelopak bunga rosela pada ayam ras pedaging dalam penelitian ini tidak mempengaruhi berat dan persentase lemak abdominalnya. Hal ini selaras dengan kajian Lohakare et al. (2004) tentang penambahan Vitamin C dalam ransum dengan dosis 10 dan 20 ppm. Hasil kajian ini menyatakan bahwa berat lemak abdomen umur 6 minggu adalah 2,7-2,9\% dari berat hidupnya. Sementara itu, laporan hasil kajian Ramli et al. (2002) menyatakan bahwa berat lemak abdomen sekitar 0,79\% dari bobot badan yang mendapat ransum difermentasi dengan Kambucha (jamur teh yang berasal dari Asia Timur). Terkait dengan tinggi atau rendahnya jumlah lemak abdomen ini, Palo et al. (1995) menyatakan bahwa umur pemeliharaan dan energi ransum dapat mempengaruhinya. Artinya, jika secara kuantitatif semakin pendek umur pemeliharaan maka jumlah lemak abdomen pun semakin menurun, sejalan dengan menurunnya persentase lemak abdomen. 


\section{Titer antibodi ayam ras pedaging} Tabel 5.

Hasil pemeriksaan titer antibodi dengan uji hambatan hemaglutinasi dapat dilihat pada

Tabel 5. Profil hasil pemeriksaan titer antibody umur 35 hari yang diberi seduhan kelopak bunga rosela terhadap penyakit ND

\begin{tabular}{lc}
\hline \hline Air seduhan kelopak bunga rosela $(\mathrm{g} / \mathrm{l})$ & Rataan titer antibodi \\
\hline T1: 0,00 & $33,33 \pm 30,02$ \\
T2: 1,30 & $10,00 \pm 6,93$ \\
T3: 2,60 & $35,50 \pm 35,23$ \\
T4: 3,90 & $23,00 \pm 27,78$ \\
\hline
\end{tabular}

Tabel 5 menunjukkan bahwa pemberian seduhan kelopak bunga rosela tidak nyata berpengaruh $(\mathrm{P}>0,05)$ pada titer antibodi ayam ras pedaging yang dipelihara sampai dengan umur 35 hari. Pemberian seduhan kelopak bunga rosela diduga dapat memicu timbulnya respon imun. Hal ini sesuai dengan pendapat Block and Mead (2003) bahwa kebanyakan tanaman obat yang sudah diteliti membuktikan adanya kerja imunostimulator yang dapat meningkatkan fungsi dan aktivitas sistem imun, sehingga dapat menekan atau mengurangi infeksi virus dan bakteri intraseluler. Di samping itu, imunostimulator ditujukan untuk mengatasi imunodefisiensi atau sebagai perangsang pertumbuhan sel-sel pertahanan tubuh dalam sistem imunitas.

Pemberian kombinasi vaksin ND dengan seduhan kelopak bunga rosela belum dapat meningkatkan titer antibodinya walaupun dilakukan vaksinasi ulang (booster) ND pada hari ke-28. Titer antibodi maksimum akan dicapai dua minggu pasca-vaksinasi. Rata-rata titer antibodi berkisar $2^{4}-2^{6}$ yang menunjukkan angka mortalitas $0 \%$ bila ditantang dengan virus lapangan (Tabbu, 2000).

Keberhasilan vaksinasi dapat dipengaruhi oleh kualitas vaksin yang digunakan, jadwal vaksinasi yang tidak tepat waktu, aplikasi vaksinasi yang salah serta adanya infeksi sekunder yang bersifat menekan sistem imun (imunosupresif) pada yang dipelihara (Tizard, 2004).

\section{KESIMPULAN}

Kesimpulan dari hasil penelitian ini adalah pemberian seduhan kelopak bunga rosela pada ayam ras pedaging belum memberikan pengaruh yang nyata terhadap berat badan akhir, berat dan persentase karkas, berat dan persentase lemak abdominal dan titer antibodi ayam pedaging. Perlu dilakukan penelitian lebih lanjut untuk mengetahui tingkat keoptimalan daya kerja air seduhan kelopak bunga rosela pada kondisi lingkungan yang tidak terkontrol baik suhu, lingkungan, penyakit dan kebersihan air minum dan pakan.

\section{DAFTAR PUSTAKA}

Block KJ, Mead MN. 2003. Immune system effects of Echinacea, ginseng and Astragalus: A review. Integr Cancer Ther. 2:247-267.

Lohakare JD, Chae BJ, Hahn TW. 2004. Effects of feeding methods (water vs feed) of vitamin C on growth performance and carcass characteristics in broiler chickens. Asian-Australasian $\mathrm{J}$ Anim Sci.17:1112-1117. 
Mardiah S, Hasibuan, Rahayu A Ashadi RW. 2009. Budidaya dan pengolahan rosella. Ed ke-1. Jakarta (Indonesia): Agromedia.

Maryani H, Kristina L. 2008. Khasiat dan manfaat rosela. Jakarta (Indonesia): Agromedia.

North MO. 1984. Comercial chicken production manual. $3^{\text {th }}$ Ed. Westport Connecticut Avi Publishing Company Inc.

Palo PE, Sell JL, Piguer FJ, Salanova MF Vilaseca L. 1995. Effect of early nutrient restriction on broiler chicken: Performance and development of the gastrointestinal tract. J Poult Sci. 74:88101.

Parry RT. 1989. Technological development in pre-slaughter handling and processing in processing of poultry. In: Mead, GC, editor. England (UK): Elsevier Applied Science.

Ramli N, Rofiq MN, Akhadiarto S. 2002. Pengaruh teh fermentasi kombucha sebagai feed aditif terhadap persentase karkas, lemak abdomen dan organ dalam ayam broiler. Dalam: Haryanto B, Setiadi B, Abdul Adjid RM, Sinurat AP, Situmorang P, Prawiradiputra RB, Tarigan S, Wiyono A, Purwadaria MBT, Murdiati TB, Abubakar, Ashari, penyunting. Prosiding Seminar Nasional Peternakan dan Veteriner. Bogor, 30 September-1 Oktober 2002. Bogor (Indonesia): Puslitbangnak. hlm. 274-276.

Rinaldi. 2004. Pemanfaatan kulit buah markisa (Passiflora edulis) dalam konsentrat terhadap performans kambing Kacang [Skripsi]. [Medan (Indonesia)]: Universitas Sumatera Utara.

Soeparno. 1994. Ilmu dan teknologi daging. Yogyakarta (Indonesia): Gadjah Mada University Press.

Steel RGD, Torrie JH. 1993. Prinsip dan prosedur statistik. Jakarta (Indonesia): PT Gramedia Pustaka.

Tabbu CR. 2000. Penyakit ayam dan penanggulangannya Vol. 1. Yogyakarta (Indonesia): Penerbit Kanisius.

Tizard IR. 2004. Veterinary immunology. In: China. WB, editor. Pickerington (US): The Saunders Company.

Wahju J. 2004. Ilmu nutrisi unggas. Yogyakarta (Indonesia): Gadjah Mada University Press.

Warwick EJ, Astuti JM, Hardjosubroto W. 1995. Pemuliaan ternak. Edisi kelima. Yogyakarta (Indonesia): Gadjah Mada University Press.

Yulrahmen, R. 2008. Performans ayam petelur umur 21-27 minggu yang diberi air rebusan daun sirih (Piper betle Linn) pada air minum. Bogor (Indonesia): Program Studi Ilmu Nutrisi dan Makanan Ternak, Fakultas Peternakan, Institut Pertanian Bogor. 